DOI 10.18551/rjoas.2021-11.20

\title{
INNOVATION OF INSTITUTIONS AND PROHIBITION RE-REVIEW OUTER-ISLAND MARKETING OF COWS TO INCREASE VALUE ADDED OF BEEF CATTLE
}

\author{
Krova Maria*, Sobang Yohanis U.L., Lalus Matheos F. \\ Faculty of Animal Husbandry, University of Nusa Cendana, Indonesia
}

Morin, Sol'uf M.

Doctoral Study Program, Faculty of Animal Science, University of Nusa Cendana, Indonesia

\author{
Doppy Roy Nendissa \\ Department of Agribusiness, Faculty of Agriculture, University of Nusa Cendana, Indonesia
}

*E-mail: mkrova30@gmail.com

\begin{abstract}
Nowadays, beef cattle marketing in production center namely Kupang Regency tends to lead to unequally depletion of farmers' value added. The farmers value added was an important thing to motivate them in using technology to increase productivity and sustainability for all actors in the beef cattle supply chain. Research objectives were to analyse the farmers' value added and to stimulate policy needed, therefore it will increase the farmers' value added. The research was a case study in the beef cattle supply chain. Key informant persons were determined by applying snow ball sampling from downstream to upstream. Number of key informants depends on saturation information and model validation result include their behaviour understanding. Data collected were numeric, written, and mental model. Data, then, were analysed by applying the value added and system dynamic modelling with Vensim software application. The result showed that the farmers have the smallest value added average of IDR 4,284,277.15 annually with profit margin IDR8,676,500.40 per year and the value added ratio was $8.49 \%$. Middlemen have the highest value added IDR $60,529,650.00$ per year and profit margin IDR61,705,650.00 per year, and the value added nisb was $14.98 \%$ decrease, followed by abbatoir traders, and the middlemen coordinator. The highest value added ratio gained by the abbatoir marketters was $21.5 \%$. The result of policy simmulation decreases the difference of cattle price between the middlemen and the farmers, and equalize the price of cow and bull. The result really can increase the farmers' value added. Further, innovation of the farmers' cooperative institution to increase the farmers' bargaining power and to re-review the prohibition of outer-island marketing cows in order to equalize the price of bull and cow.
\end{abstract}

\section{KEY WORDS}

Value Added, beef cattle, innovation of institutions, system dynamic.

Nowadays, there is a phenomen on small farmers level that tends to deplete beef cattle production but unequal to the farmers value added gained. Krova et al (2020) research showed that the cattle sold by the farmers were not only the ready slaughtered cattle but also the productive cows include heifers, but some indicators of economic wealth such as income level and an access to the high education level were relatively low.

The value added was important for the farmers to motivate them in using technology as an effort to increase productivity and sustainability of the farm for all actors in the beef cattle supply chain. The low productivity and bargaining position affected low household income and these two factors were the main reasons for the farmers to sell all of their assets.

Anderson and Hanselka (2009) stated that "Value added" means adding value to a raw product by taking it to at least the next stage of production. Creating the value added can be done by the right understanding about costomer segment who wants the product produced, product usefulness wanted by the potential costumer, and criteria needed when they buy the 
product. Commonly, the value was made by focusing on its usefulness relates to the product or agribusiness service bears, such as: quality, form, place, time, and possesion. The customer wants only can be known when the farmers can participate in the market.

A study was conducted by Kibona and Yuejie (2021) in order to evaluate factors influence the beef cattle farmers' participation in the market in Meatu District region of Simiyu, Tanzania. The study showed that the market participation of the beef cattle farmers was the key to make sure that they gain a better income, food security, and beef supply sustainability. Roy et al. (2018) about Beef market integration in East Nusa Tenggara of Indonesia, Roy et al. (2018) about Dynamics of degree of beef cattle market concentration in Kupang of East Nusa Tenggara, and Maria et al (2019) about Alternative policies for saving productive Balinese cows for controlling cuts. In contrast, the farmers in Kupang Regency have such characteristics namely low sell volume, low level education, and bad access to credit and veterinary services as the main factors of the market participation barriers.

There were many efforts done by the governments of Kupang Regency and East Nusa Tenggara (ENT) Province, namely: programs of extension, siwab, and kopel but the programs target were limited to support the productivity. Actually, the programs must be followed by the increasing of the farmers' market participation to gain value added that bears sustainability insentive and farm development. Further, the increasing of productivity unfollowed by the increasing of the farmers' participation in the market will produce low value added.

The beef cattle marketing has a specific supply chain pattern and it covers many actors with their specific importance. An efficient supply chain was integrated, but according to Simchi-Levi et al (2000) the supply chain integration was a difficult work due to the existing of difference and objectives conflict, fascilities, and the actors participated. The beef cattle supply chain itself was a dynamic system that develops all the time. Thus, the problem in the beef cattle supply chain was a complex problem and dynamic, therefore it needs a right analysis to find its solution. The right analysis to this problem was dynamic system.

The research was conducted with two objectives. The objectives were to analyse the farmers' value added among the others actors in the beef cattle supply chain in Kupang Regency and to stimulate policy needed both in the farm management and in the beef cattle supply chain management in order to increase the farmers' value added.

\section{METHODS OF RESEARCH}

The research was a case study in beef cattle supply chain management. The research population were all actors along the beef cattle supply chain namely the cattle buyers who buy the cattle from the farmers in Kupang Regency West Timor. Informant key actors were determined by applying snow ball sampling method started from downstream covers abbator's traders and inter-island traders at Lili Market as the only one market in West Timor. Based on the information from those traders, it will be known the village of the farmers who sell the cattle either to the abbatoir traders or to the outer-island traders.

Number of the key-informant depends on information saturated gained and information validation result about behaviour and real structure gained with model structuring and behaviour understanding. Data, information, and primary knowledge were collected based on observation, Focuss Group Diskusi (FGD), and indepth study with ket informants. The collected data comprises three kinds of data namely: numeric, written data, and mental model.

Based on the previous formulated objectives, the analysis method done were value added, ratio of value added, and profit margin (Hayami and Kawagoe, 1993).

$$
\begin{gathered}
\text { Value Added = Ouput Value - Other Output Value - Raw Material Value } \\
\text { Profit Margin = Ouput Value - Raw Material Value }
\end{gathered}
$$

Moreover, a formulation was applied to evaluate supply service contribution of every channel towards output value. The formulation was as follows: 


$$
\text { Ratio of Value Added }=\frac{\text { Value Added }}{\text { Output Value }} * 100 \%
$$

Further, in order to simulate policy, it needs system dynamic modelling. The system dynamic modelling will use a software called Ventana Simulation (Vensim). The software was used on stages of drawing cause-effect diagram, drawing flowchart or sub model diagram (level and rate) based on the system studied, stage of the system model development, stage of testing assumption, and stage of simulation.

Result of the model planned, then, validated covers dimension, strukture, behaviour, include its policy. If the results of validation and test (using time series data) showed that the behaviour model of actual beef cattle supply chain management has not been valid yet, thus, it will be structured again. Then, if the model has already valid, it will be suggested policy changing in accordance with the problem in the system.

\section{RESULTS AND DISCUSSION}

Value Added among Actors in Beef Cattle Supply Chain in Kupang Regency. Analysis of value added distribution applying some indicators such as value added, ratio of value added, and profit margin. Time unit of value added calculation and the farmers' profit margin as well as the traders were calculated in time unit per annum.

The result analysis of Table 1 showed that among all actors in the beef cattle supply chain management in Kupang Regency, the highest value added was gained by the middlemen at IDR66,409,650,00/year followed by the abbatoir traders, coordinator of the middlemen, and the farmers were gained the lowest value added at IDR4,284,277.15. The result of analysis found that there were 2 differences of the value added which relatively high among the farmers and the middlemen as the second supply chain after the farmers. This condition existed because the farmers need cash money. The same case reported by Nalle and Tiro (2019) that $50 \%$ of the farmers stated that the first reason they sell their cattle was for their children education fee. The second reason mentioned by $32.50 \%$ of the farmers was to fulfill their daily needs. Then, after buying the cattle, the middlemen will sell the cattle at the highest profit price at IDR500,000.00 per head.

The result of analysis also showed that the value added accumulation gained by the farmers was very low. This condition refers to a high production cost with a long production duration of beef cattle (1,5 to 3 years). In contrary, the middlemen only spent transportation cost and they can earn profit in 1 to 4 weeks at IDR400,000 up to IDR1,000,000. Those facts were indicated that why the farmers in Kupang Regency have low level of economic wealth and their farms were hardly enough to be developed. This research was relatively different from the research conducted by Heatubun et al (2020) in Sub-district of Lolong Guba, Regency of Buru, Province of Maluku. This research objectives were to analyse the value added produced by the the beef cattle farmers and cattle slaughterers. The research result showed that the farmers' value added was higher than that of the slaughterers.

Table 1 - Average of Value Added, Ratio of Value Added, and Profit Margin per Year of the Actors in the Beef Cattle Supply Chain in Kupang Regency

\begin{tabular}{|l|l|l|l|l|}
\hline No & Actors in the Supply Chain of Beef Cattle & Value Added (IDR) & Vaule Added Nisb (\%) & Profit Margin (IDR) \\
\hline 1 & Farmers & $4,284,277.15$ & 14.20 & $8,676,500.40$ \\
\hline 2 & Middlemen & $66,409,650.00$ & 16.20 & $67,585,650.00$ \\
\hline 3 & Middlemen Coordinator & $54,024,700.00$ & 11.65 & $57,565,200.00$ \\
\hline 4 & Abbatoir's Traders & $54,179,255.97$ & 21.58 & $55,355,255.97$ \\
\hline
\end{tabular}

Based on the aspect of value added ratio, actually, the abbatoir's traders have the highest value added ratio at $21.5 \%$ comparing with the other actors. Further, it was followed by the middlemen at $16.20 \%$, farmers (14.20\%) and the last was the middlemen coordinator $(11.65 \%)$. This result showed that the abbatoir's traders have the biggest service contribution towards final output value if devided it by the cattle sold. This analysis can be understood because the abbatoir's traders mainly select raw materials namely cow with a 
relatively low price comparing with the bull bought by the middlemen and the middlemen coordinator with a relatively high price.

Based on the profit margin analysis result, it can be seen that the middlemen have the highest profit margin followed by the middlemen coordinator, the abbatoirs traders, and the lowetst was gained by the farmers. The lowest profit margin gained by the farmers was affected by low value of output and cattle breed extinction cause a high price of raw material or its input.

These conditions showed that the farmers got a high pressure of selling price. In fact, the farmers in Kupang Regency have no other alternative buyers except the local middlemen at their region. This facts due to a relatively high of transaction cost spent by the farmers so they prefer to sell their cattle on their farm gates. Refers to the research conducted by Nalle and Tiro (2019) which found that there were some dominant factors determinated the farmers to choose to sell their cattle at their farm location through the middlemen. The determinated factors were kind and retribution cost of livestock market, feed cost, and the farmers consumption cost. In long term, the value added gained gap between the farmers and the middlemen did not support the beef cattle development in Kupang Regency. Therefore, it was neccessary to find a policy so the farmers will not sell their cattle in urgent needs.

System Dynamic Modelling of Beef Cattle Supply Chain in Kupang Regency. According to the value added result analysis, a system dinamic model was formulated in order to evaluate actual behaviour and the model ability in simulating a policy scenario to increase the value added on the farmers' level. Then, a structured flow diagram model was validated previously before evaluating actual behaviour and scenario application.

The exacted model was a model describes the behaviour as real as fact. Therefore, various validation tests were done in order to establish a trust worthy model. Sterman (2000) explained about a test that can be applied to evaluate a dynamic model which adapted and developed by Forrester and Senge (1980). The model testing was classified into three tests, namely model structure test, model behaviour test, and policy implication model test.

In order to testify the established model ability that causes behaviour reproduction model ability which relevant to the real system, some statistical tests were done, namely: $r$, RMSPE, and Theil test (UM, US, and UC). Value of coefficient correlation result ( $r$ ) of those five tested parameters were more than 0.90 and less than 1 . The test result showed that historical and simulated result data have a high correlation. Statistical test result of Root Mean Square Percent Error (RMSPE) showed a relatively value less than 0.2 . This result described that Theil coefficient (Theil's Inequality Coeficient or $U$ ) was useful for evaluating the model ability and it was valid to do a forecasting. Deviation propotion value (UM ) and varians proportion value (US) of the model was very small or close to zero, at range of 0.0001 up to 0.11 and 0.0004 up to 0.21 . On the other hand, the covariant propotion value (UC) was relatively high at range of $0.64-099$ ) (Table 2).

Table 2 - Data Statistical Test Recapitulation of Simulation Result

\begin{tabular}{|l|l|l|l|}
\hline \multirow{2}{*}{$n / n$} & \multicolumn{2}{|l|}{ Beef Cattle on the Farmers' Level } & \multirow{2}{*}{ Bali Cattle Selling the Coordinator of Middlemen } \\
\cline { 2 - 4 } & Female Calf & Heifer & \\
\hline$r$ & 0.98 & 0.96 & 0.99 \\
\hline RMSPE & 0.11 & 0.19 & 0.04 \\
\hline$U^{M}$ & 0.06 & 0.11 & 0.08 \\
\hline$U^{S}$ & 0.01 & 0,07 & 0.21 \\
\hline$U^{C}$ & 0.87 & 0.73 & 0.64 \\
\hline
\end{tabular}

Anomaly behaviour test was done to evaluate wether the anomaly behaviour was increased if an assumption of the model was erased (Tasrif, 2012). This case can be done by changing assumption equilibrium to disequilibrium, checking, and improving the found anomaly behaviour. If the anomaly behaviour still exists, therefore structure and parameters improvement were neccessary. 
Actual Value Added Behaviour of the Beef Cattle Farmers. Phisycal structure and decision in the supply chain management of the beef cattle in Kupang Regency which has been modelled has a dynamic behaviour. The dynamic behaviour caused by the existing of time changing and related components in any sub of the Bali cattle development model that has been modelled before. The research was conducted to discuss behaviour related to the ability of actual beef cattle supply chain management considering fairly value added to sustain beef cattle agribusiness in Kupang Regency.The beef cattle agribusiness development will be showed by the behaviour of any factor in every subsystem. Therefore, it will be explained about important indicator in relation to the management supply feeder, namely: population structure of cow, female calf, heifer; production of male Bali cattle ready to be slaughtered; and value added on each level of the actors in the supply chain.

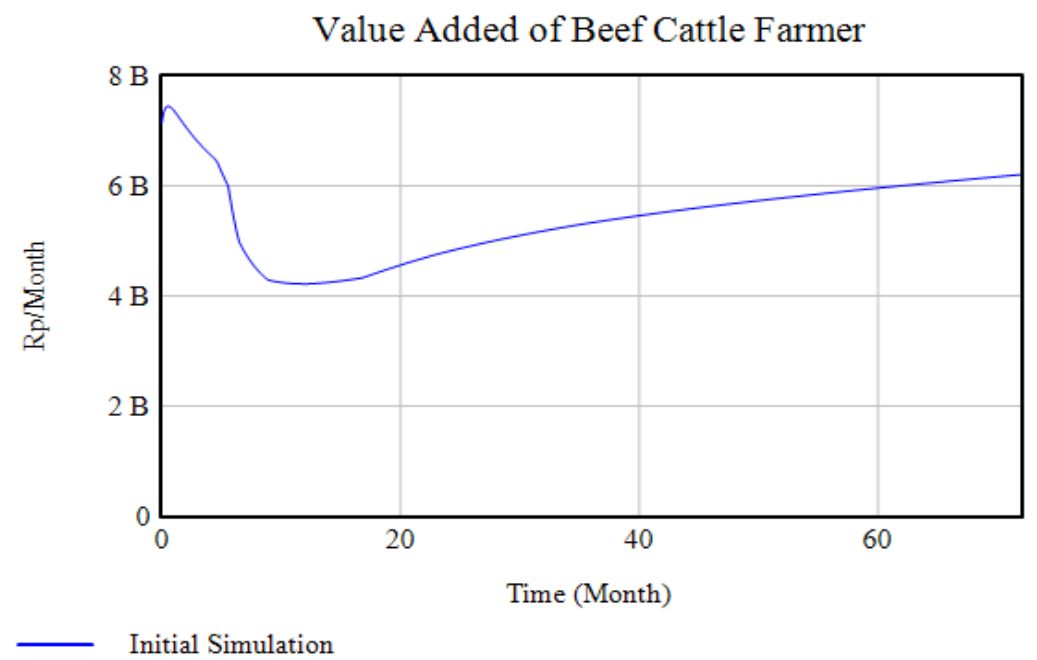

$\begin{array}{ll}\text { Year of } & \text { Previous Simulation } \\ 1 & 4.22196 \mathrm{e}+09 \\ 2 & 4.81329 \mathrm{e}+09 \\ 3 & 5.33474 \mathrm{e}+09 \\ 4 & 5.68535 \mathrm{e}+09 \\ 5 & 5.9642 \mathrm{e}+09 \\ 6 & 6.2089 \mathrm{e}+09\end{array}$

Figure 1 - Actual Performance of the Actual Farmers Value Added

Time determination of the begining simulation was at 2018. Therefore, duration of historical data and forecasting data were as same as during 3 years so total time in this simulation were 6 years or 72 months. A historical data from the years of 2018 to 2020 (the first month to the time until 36 months) and the simulation data started from the year of 2021 to 2023 (or at the month of 37 to the month of 72). Actually, the historical data that will be applied to validate the simulation result data was in accordance with the available data of Bali heifer and female calf, include selling data on the level of the middlemen for domestic market. Previous simulation condition was determined based on the equilibrium condition of the model. Parameters value used in the model were gotten from some resources, such as: related literature, analysis result of numeric data, interview result to the specialist and keyinformants participated in the beef cattle supply chain.

Figure 1 showed that the farmers' value added of the beef cattle farm in Kupang Regency described an increasing trend but it was still on the low relatively value. It was caused by two main variables that formulate the value added namely the cattle number and the cattle price were still very low on the farmers' level. Based on the previous actual simulation result, it was found that the beef cattle population structure tends todecrease because the farmers applying simple management raising system without technology approachment both on reproduction and feed. These conditions influence the beef cattle 
performance and it decreases cattle price. Additionally, limited information access and unsufficient facilities cause the decreasing of the beef cattle price on the farmers' level. Therefore, it will be planned policies that hopefully can increase number of the beef cattle so the farmers' value added as the cattle producers.

Policy Analysis to Increase the Beef Cattle Farmers' Value Added. Understanding result through the flowchart showed that flows of management and supply of ready to be slaughtered beef cattle on the farmers' level have not been optimum yet. There were some problems faced as leverage point that must be interventioned in order to get an improvement, namely low calving rate, high mortality number, a big price difference (price gap) between the price of male cattle occurs on the farmers' level comparing with the price on the middlemen level, and the price difference between cow and bull. The objectives of intervention to increase calving rate and to decrease mortality were to increase selling volume therefore the market participation will increase were done and reported by Krova, et al (2019 and 2020). The policy analysis scope only focused on intervention simulating of price difference occurs to the increasing of the farmers' value added. Therefore, the managements of the farm and beef cattle supply chain were needed to be interventioned by any other responsible institution so the farmers' value added can be increased.

Some scenaries to increase the farmers' value added can be done by: 1) increasing the bull price on the farmers' level by increasing the farmers' bargaining power, and 2) equalising the price of the cow and bull (Table 3).

Table 3 - Actual Condition Simulation Parameter Model and Scenaries to Increase the Farmers' Value Added

\begin{tabular}{|l|l|l|l|}
\hline \multirow{2}{*}{ Policies } & \multirow{2}{*}{ Actual Condition } & \multicolumn{2}{|l|}{ Scenario } \\
\cline { 3 - 4 } & 8.1 & I & II \\
\hline Increasing the bull price (in million) & 6.5 & 8.5 & 0 \\
\hline Equalising average price of cow and bull (in million) & 0 & 7.5 \\
\hline
\end{tabular}

The first scenario declines the price difference among the farmers and the middlemen. The scenario was done based on the improvement of the farmers' bargaining power so the cattle marketing could not occur individually. This principle was important because the farmer individually has a weakness bargaining power to determine the cattle price. As price takers the selling price was low and the low selling volume makes low income. Therefore, it is better for the farmers to be the members of a cooperative in order to reach this scenario objectives. Cooperative was an innovative institution to save and to lend money as well as to distribute the beef cattle sold by the farmers. It means the middlemen will face the cooperative in relation to the cattle bargaining. Therefore, hopefully, this activity will reduce the price gap between the middlemen and the farmers.

The second scenario was done because the farmers always get a big price pressure deal with the cows. The price difference between cow and bull at the same age can reach at IDR500,000/head up to IDR1,000,000/head. The difference price occurs due to a prohibition of selling outer island of productive cows. By applying the same price between cow and bull will increase the beef cattle farmers' value added.

Policy Simulation to Increase Bull Price. The scenario I was done through institutions innovation on the farmers' level by establishing a legal cooperative. This scenario was in accordance with Kibona dan Yuejie (2021) study on traditional beef cattle farmers in the Meatu District of Simiyu Region, Tanzania which recommended that the establishing of strategic cooperative was not only function as a communication channel of agricultural credit, price, market information, and commercial agriculture training, but also to help the farmers in choosing the profitable market. The cooperative objectives were to increase the cooperative services in supplying inputs for the farmers and to market their products. It was an important thing for the cooperative services to prepare the cash money to fulfill the farmers needed because the cattle role was as saving for the farmers. Sometimes the farmers sell their cattle to get cash money. Regarding the cash money, particularly in urgent situation, the farmers' bargaining position will weak in relation to negosiate the cattle price with the traders. 


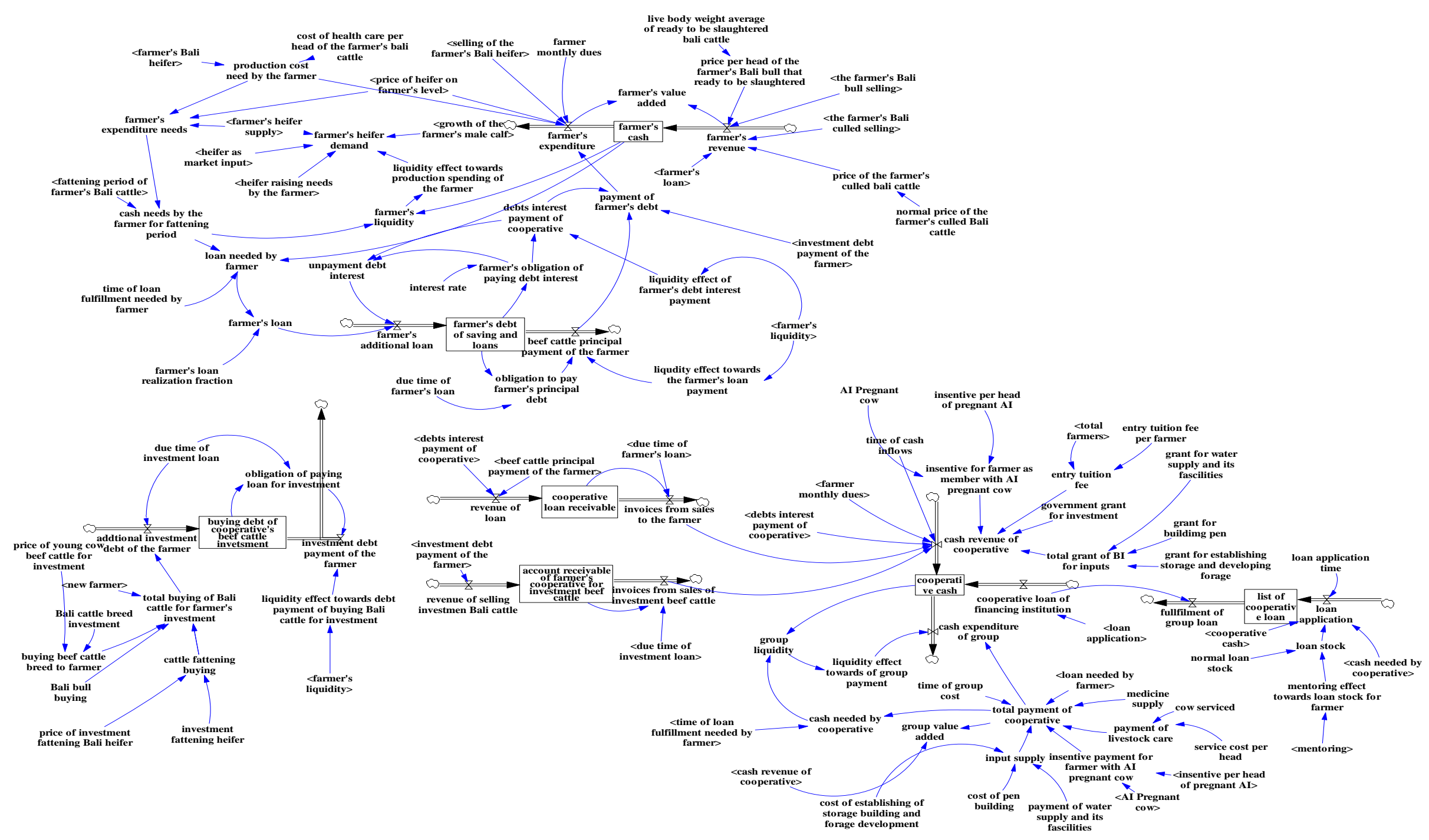

Figure 2 - Scenario I Increasing the Farmers Cash and Beef Cattle Cooperatives Cash 
Cooperative services such as buying inputs in a big scale can decline the input price per unit so the farmers will get the relatively lower price inputs. The inputs were tether ropes, concentrate feed, supplemment, and medicine. The available of the inputs surround the farmers will helpful and make them easier to get the inputs.

In the scenario I, the farmers' bargaining position in the beef cattle marketing increased because the farmers sell their cattle not in individually way but through the cooperative (Figure 2). The cooperative acts as collector and seller. The selling process can occur when it profitable for the farmers and the cooperative. In case of needed the cash money, the farmers, then, can borrow the money from the cooperative and payback it after the cattle was sold. Evenly, the cooperative can sell the cattle directly to the middlemen coordinator or the cooperative can be play as outer island trader. This suggestion adopted the experience of the East Nusa Tenggara Province Cooperative which sell directly the ready slaughtered cattle to the supplyers in Jakarta. Therefore, the cattle price on the farmers level was higher. The scenario I was done by additing the saving structure and borrowing structure of the cooperative. The cooperative can act as the storager or collectoof the beef cattle and supply the cattle to either to the middlemen or to the middlemen coordinator. The price gained by the cooperative was the average price on the middlemen level at $30,000,-$ per $\mathrm{kg}$ live bodyweight.

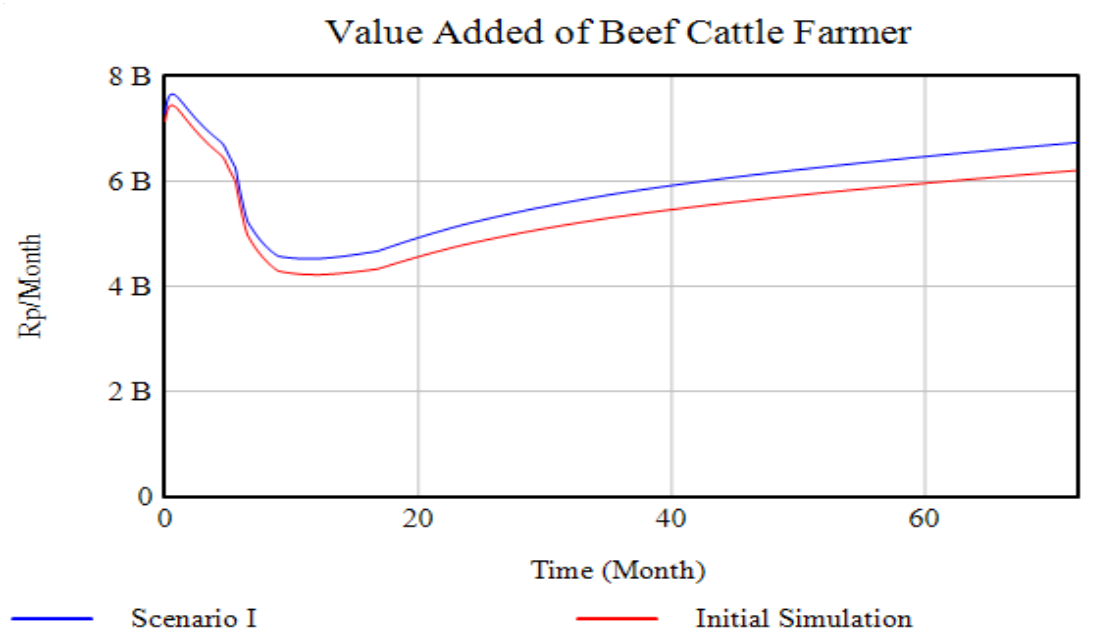

Quantitative Data of the Farmers' Value Added

$\begin{array}{lll}\text { Year of } & \text { Previous Simulation } & \text { Scenario I } \\ 1 & 4.22196 \mathrm{e}+09 & 4.37518 \mathrm{e}+09 \\ 2 & 4.81329 \mathrm{e}+09 & 5.00702 \mathrm{e}+09 \\ 3 & 5.33474 \mathrm{e}+09 & 5.55691 \mathrm{e}+09 \\ 4 & 5.68535 \mathrm{e}+09 & 5.92555 \mathrm{e}+09 \\ 5 & 5.9642 \mathrm{e}+09 & 6.21811 \mathrm{e}+09 \\ 6 & 6.2089 \mathrm{e}+09 & 6.47333 \mathrm{e}+09\end{array}$

Figure 3 - Result of Scenario I towards Value Added of Farmer

The source of structure cooperative revenue was institutions loan as partner of the cattle farmers' cooperative both Cooperative Institution include Small and Medium Entreprise Scale (SMES) or the other financial institution. Other sources of the revenue were from the farmers comprise: cooperative base money was IDR100,000 per person, mandatory saving was IDR5,000,-/person/month, voluntary saving was 50,000.00-/person/month, medicine and vitamin fees for the cull cattle was IDR75,000,- per head, medicine fee for fattening heifer was IDR50,000.00 per head. These revenue sources were the revenue of the farmers' cash. The other revenue structure of cooperative was gained from selling the cattle that will be spent as payment for the farmers. Values of variables and parameters in the cooperative scenario were hypotetic values. 
On the other hand, the cooperative cost structure consist of loan that the farmers needed and the payment gaining from the selling of the farmers' cattle were the revenue for the farmers. However, the cost of buying heifers need by the farmers, include supplying medicine and vitamins were cooperative cost structure of fee and costs that must be spent by the farmers. The cooperative operational cost and total payment loan for the cooperative partner as the cost of the cooperative in managing loan fund and cooperative administrative.

Simulation result (Figure 3 ) showed that the farmers' value added on previous simulation lower that that of scenario I although there was a decreasing in a few months before the end of the scenaried time. It means it was more profitable if the farmers be the members of stronger cooperative because it can increase their bargaining power and make shorter the distribution channel of the beef cattle. The increasing of profit on scenario I was caused by the beef cattle price level of on the farmers' level of previous simulation was IDR28.000,- per kg live bodyweight increases to IDR30.000,- per kg live bodyweight at the same price on the middlemen.

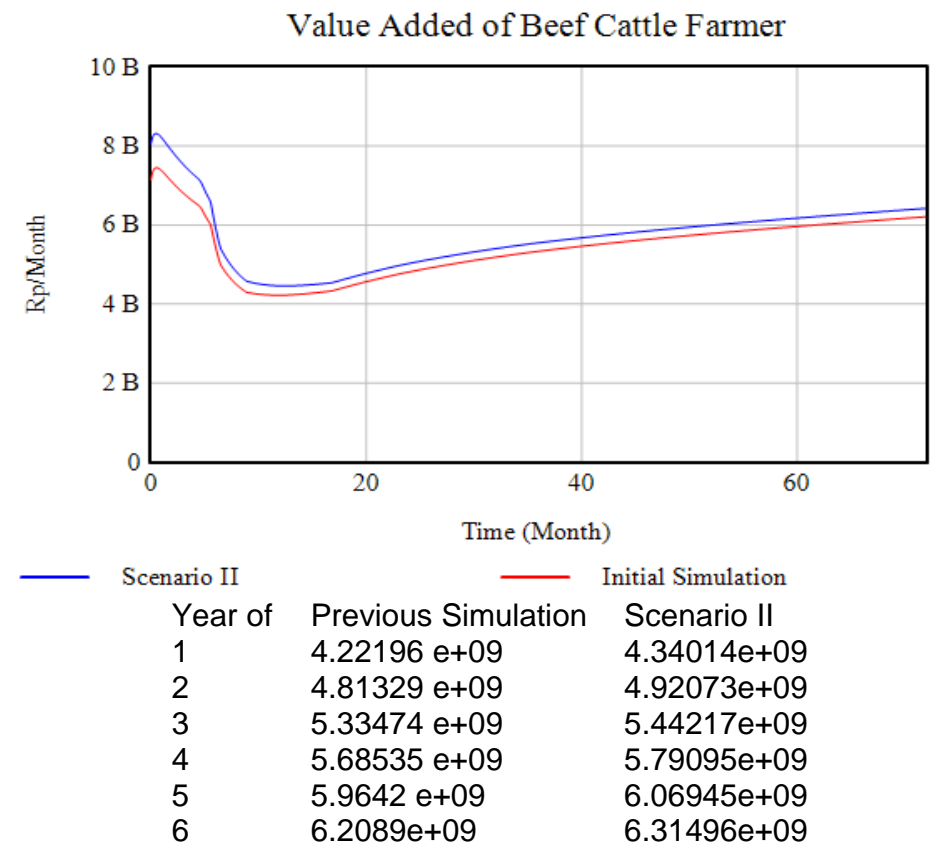

Figure 4 - Result of Scenario II towards the Farmers' Vaule Added

Result research of Arief, et al (2019) in order to evaluate feasibility and management of dairy cows focused on saving and loan credit recipient of SAE Cooperative in Pujon, at Malang, East Java showed that the saving and loan credit business has positive influence on the business feasibility. According to Republic of Indonesia Constitution Number 17 Year of 2012, cooperative was a legal institution established privately or legal entity by separating the members' wealth as capital to run business, that fulfill aspiration and together needs in economy, social, and culture in accordance with value and principle of cooperative.

Besides through cooperative, the farmers' bargaining power can be increased through the cattle auction which its facilities were prepared by the government. The auction can be done nearby the cattle farm so no transportation and accomodation costs spent.

Scenario II, A Policy to Equalize the Price of Male and Female Beef Cattle. One problem decreases the farmers' value added was the price of female cattle was lower than that of male cattle. The difference price of the female cattle caused by selling quota of outerisland marketing. Governor's regulation Number 78 Year of 2019 was applied to control inflows, outfolws, and distribution of livestock/animal products and their by-products in East Nusa Tenggara. On the article of 9 about outflows stated that: 1) big ruminants that can be sent to the other region were the ready to be slaughtered livestock, 2) the male big ruminant for breeding can not be allowed to be sent to the other region, 3) the female big ruminant for breeding or not can not be allowed to be sent to the other region. This regulation was done 
by the government to prevent the productive female ruminant accumulation send out in production center areas.

The policy impact causes the limitation of cows market occurs only in local market without other alternative market. If the male cattle price decreased from domestic market, followed by the price at level of the middlemen coordinator, and the price at level of the middlemen until the price at the farmers' level. The cow price was determined by the abbatoir's traders as the only one buyer and in small quota. In fact. the outer island prohibition causes the cows were dominantly bought by the abbatoir's traders (it reaches about 80 persen) because the cow's price range was IDR500,000.00 up to IDR 1,000,000. Priyanti et al (2017) stated that the slaughtering cows in Bali, Nusa Tenggara and South Sulawesi Selatan reached $72 \%$ on average of total slaughtering number; it means more than $90 \%$ were productive cows. The following factors were the reasons to slaughter the productive cows: (1) the cow's price was cheaper 2) the availability of bulls; (3) quota policy for outer-island marketing; (4) unconcistention of law applying; and (5) the understanding criterias has not been applying yet mainly by the farmers.

Equalisation the cow price was based on the opinion that the cow bought on lower price at the farmers' level was interested, since after processing, the price of the cow beef and carcass has no difference comparing with the bull carcass or meat. Government policy was urgent to re-consider the policy in relation to kind of livestock outer-island marketing.

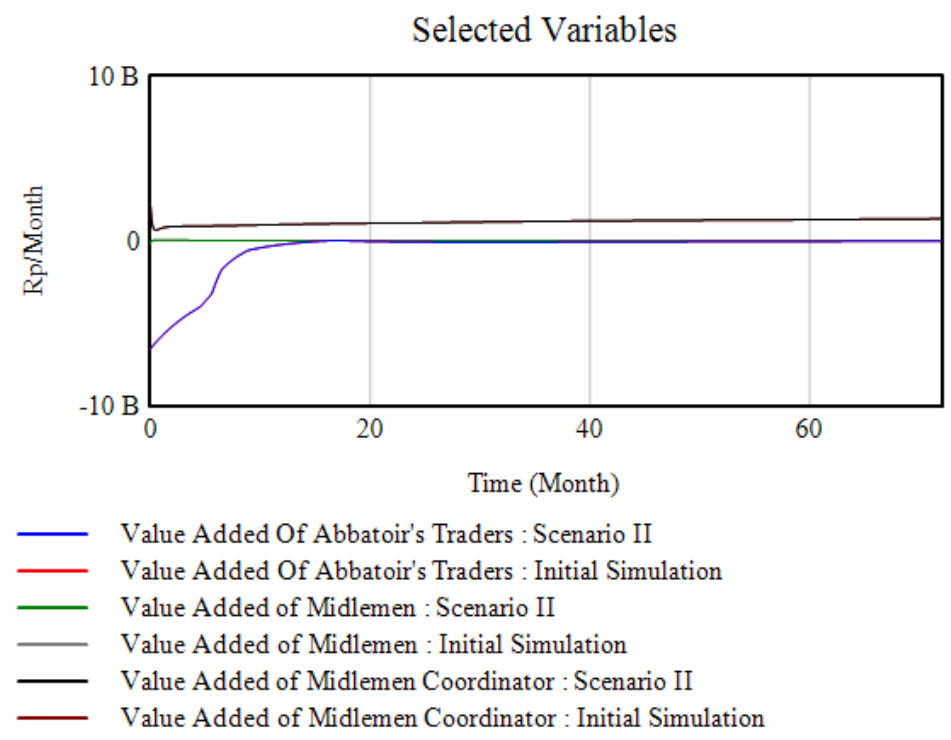

Figure 4 - Result of Scenario II towards Value Added of Traders

Simulation result of Figure 4 showed that by implementing the same price between the price of cow and bull. Further, the farmers' value added will increase. The increasing of the value added was the main point in increasing the beef cattle population in Kupang Regency. This condition exists due to the increasing of the value added can be used for the farmers' insentive in adopting technology to increase productivity either through the increasing of calving rate or decreasing mortality (Krova, et al, 2019).

Scenario II also showed that the equalisation price of cow and bull has no effect in increasing the value added of the middlemen, coordinator of the middlemen, and abbatoir's traders (Figure 6). This condition was very useful to decrease the value added gap among the actors in the supply chain. Therefore, the government should consider or review again the policy of marketing the cows to the outer island as well as the other policy considering value added for the farmers in increasing cattle population. In fact, the policy causes the increasing of cows selling.

\section{CONCLUSION}


Based on the result and discussion, it can be concluded that:

- Value added among the actors in the beef cattle supply chain management in Kupang Regency has not been distributed fairly yet. Comparing with other actors, the farmers tend to have relatively small value added. The highest value added was gained by the middlemen followed by the abbatoir's traders, and the middlemen coordinator;

- There were two policies needed in the beef cattle supply chain management to increase the farmers' value added; to increase the bull price through cooperative institution innovation, and to equalize the price of cow and bull by re-reviewing the policy of cow's marketing to the outer island. Result analysis of intervention behaviour of those two policies can increase the value added on the farmers' level. Hopefully, it can decline the value added gap between the farmers and the the beef cattle marketing channel in Kupang Regency.

Some recommendations to improve fairly value added in the beef cattle supply chain management were as follow:

- The government should re-review the policy of selling cows to outer island so local traders will not pressure the cow's price. The farmers, then, should be understood to cows through intensive extension;

- Government or university must facilitate the establishing of the farmers' cooperative so the exchange function of beef cattle can be done through the cooperative institution with the members were all of the beef cattle farmers. This activities needed to increase the farmers' barganing power from the middlemen in the beef cattle supply chain.

\section{REFERENCES}

1. Anderson, D.P., and D. Hanselka, 2009. Risk Management, Adding Value to Agricultural Products. Agrilife Extension. Texas A \& M System.

2. Arief, F., N. Hariyani, Soeharsono, , W. P. Lokapirnasari, M. Lamid. A. Al Arif, 2019. Analisis Kelayakan dan Manajemen Usaha Peternakan Sapi Perah Penerima Kredit Simpan Pinjam di Koperasi SAE Pujon. Jurnal IImu dan Teknologi Peternakan Tropis, September 2019, 6(3):327-333. P-ISSN: 2406-7489, e-ISSN: 2406-9337.

3. Forester, J.W. and Senge, P.M., 1980. Test for Building Confidence in System Dynamics Models. TIMS studies in Management Science, 14, 209-228. North-Holland Pub. Company.

4. Hayami Y., Kawagoe T., 1993. The Agrarian Origins of Comerce and Industry: A Study of Peasant Marketing in Indonesia. Sint Martin Press, New York.

5. Heatubun, A., M. Veerman, dan M. J. Matatula, 2020. Analisis Nilai Tambah (Value Added) Peternak dan Pejagal atas Biaya yang Diciptakan pada Pemasaran Sapi Potong di Kecamatan Lolong Guba, Kabupaten Buru, Provinsi Maluku. Agrinimal, Jurnal IImu Ternak dan Tanaman. Volume 8 No 2 (2020). E-ISSN: 2728-2697 p-ISSN: 2088-3609.

6. Kibona, C.A., Z. Yuejie (2021) Factors that influence market participation among traditional beef cattle farmers in the Meatu District of Simiyu Region, Tanzania. PLOS ONE | https://doi.org/10.1371/journal.pone.0248576 April 1, 2021.

7. Krova, M., M. F. Lalus, Kleden, M.M., 2020. Policy for increasing feeder stock of Bali cattle (Bos javanicus domesticus) in Kupang District. Journal of Animal Science and Veterinary Medicine, Volume 5(6), pages 235-248), December 2020. ISSN 2536-7099.

8. Krova, M., Sogen, J. G., Lalus, M.L., 2019. Alternative Policies for Saving Productive Balinese Cow for Controlling Cuts. Russian Journal of Agricultural and Socio Economic. ISSUE 9 (93), September 2019. ISSN 2226-1184.

9. Nalle, A. A., dan M. Tiro, 2019. Analysis of Transaction Cost In Beef Cattle Supply Chain In West Timor, East Nusa Tenggara Province. Jurnal Nukleus Peternakan (Juni 2019), Volume 6, No. 1:38-46 p-ISSN: 2355-9942, e-ISSN:2656-792X. 
10. Priyanti, A., Inounu, dan N. Ilham, 2017. Pencegahan Pemotongan Sapi Betina Produktif melalui Tata Kelola Lembaga Korporasi Perusahaan Daerah (Prevention of Productive Cows Slaughter through Management of Local State Enterprises). WARTAZOA Vol. 27 No. 2 Th. 2017 HIm. 053-066 DOI: http://dx.doi.org/10.14334/wartazoa.v27i2.1405.

11. Roy, N. D., Ratya, A., Nuhfil, H., \& Wahib, M. A. (2018). Beef market integration in East Nusa Tenggara of Indonesia. Russian Journal of Agricultural and Socio-Economic Sciences, 80(8).

12. Roy, N. D., Ratya, A., Nuhfil, H., \& Wahib, M. A. (2018). Dynamics of degree of beef cattle market concentration in Kupang of East Nusa Tenggara, Indonesia. Russian Journal of Agricultural and Socio-Economic Sciences, 78(6).

13. Simchi-Levi, D., Karminsky, P., Simchi-Levi, E., 2000. Designing and Managing the Supply Chain. Irwin MCGraw Hill, Boston.

14. Sterman, 2002. System Dynamics: System Thinking and Modelling for a Complex World. Working Paper Series at Engineering Systems Division Massachusetts Institute of Technology. Boston.

15. Tasrif, M., 2012. Kursus Analisis Kebijakan Menggunakan Model System Dynamycs. Development Studies Foundation, ITB. Bandung.

16. Widiati, R. and Tri Satya Mastuti Widi, 2016. Production Systems and Income Generation from the Smallholder Beef Cattle Farming In Yogyakarta Province, Indonesia. Animal Production. 18(1):51-58, January 2016 Accredited by DGHE No. 81/DIKTI/Kep./2011. ISSN 1411-2027. 